\title{
PENGARUH IMPLEMENTASI ASESMEN OTENTIK DALAM PEMBELAJARAN TERHADAP HASIL BELAJAR GAMBAR TEKNIK DENGAN PENGENDALIAN BAKAT MEKANIK DI KELAS X TKRO SMK NEGERI 3 SINGARAJA
}

\author{
Aprianto Gede ${ }^{1}$, Candiasa I Made ${ }^{2}$, Gita I Nyoman ${ }^{3}$ \\ Program Studi Penelitian dan Evaluasi Pendidikan, Program Pascasarjana \\ Universitas Pendidikan Ganesha \\ Singaraja, Indonesia \\ e-mail: gedeaprianto4@gmail.com¹, candiasa@undiksha.ac.id², \\ nyomangita@gmail.com ${ }^{3}$
}

\begin{abstract}
Abstrak
Tujuan utama penelitian ini adalah untuk mengetahui pengaruh implementasi asesmen otentik yang terdiri dari asesmen proyek dan asesmen kinerja terhadap hasil belajar gambar teknik dengan pengendalian bakat mekanik yang dilakukan di kelas X TKRO SMK Negeri 3 Singaraja. Penelitian ini merupakan jenis quasi experiment dengan rancangan single factor independent groups design with use covariate. Sampel penelitian berjumlah 70 orang siswa yang diambil menggunakan teknik random sampling. Pengumpulan data dilakukan dengan metode tes obyektif dan uraian. Hipotesis pada penelitian ini diuji dengan Anakova satu jalur. Hasil penelitian menunjukkan bahwa : Pertama, hasil belajar gambar teknik siswa yang diberi penerapan asesmen proyek lebih baik daripada siswa yang diberi penerapan asesmen kinerja ( $t_{\text {hit }}=2,303 ; p \leq 0,05$ ). Kedua, setelah dilakukan pengendalian terhadap bakat mekanik, hasil belajar gambar teknik siswa yang diberi penerapan asesmen proyek lebih baik daripada hasil belajar siswa yang diberi penerapan asesmen kinerja ( $\left.F_{\text {hit }}=49,204 ; p \leq 0,05\right)$. Ketiga, terdapat kontribusi bakat mekanik $(86,2 \%)$ terhadap hasil belajar gambar teknik $(R=0,929$; thit $=20,620 ; p \leq 0,05)$. Atas temuan tersebut, disimpulkan bahwa asesmen proyek dan bakat mekanik mempunyai pengaruh terhadap hasil belajar gambar teknik pada siswa kelas $X$ TKRO SMK Negeri 3 Singaraja.
\end{abstract}

Kata kunci: asesmen otentik, hasil belajar gambar teknik, bakat mekanik

\begin{abstract}
The main objective of this study was to determine the effect of authentic assessment implementation consisting of project assessment and performance assessment towards the technical drawing learning achievement by controlling mechanical talent in $X$ TKRO class at SMK Negeri 3 Singaraja. The study employed a quasiexperimental type with a single factor design independent groups design with use covariate. There were 70 students as the samples of the study that determined by random sampling technique. The data were obtained through objective test and essay method. The hypothesis in this study was tested by a one-way Ancova. The results showed that: a) the technical drawing learning achievement of the students that applied project assessment were better than the learning achievement of students who were applied performance assessment (thit= 2.303; $p \leq 0.05$ ), b) after controlling for mechanical talent, the technical drawing learning achievement of the students applied project assessment were better than the students who applied performance assessment ( $\left.F_{\text {hit }}=49.204 ; p \leq 0.05\right)$, c) there was a contribution of mechanical talent $(86.2 \%)$ to the technical drawing learning achievement $(R=0.929$; $\left.t_{\text {hit }}=20.620 ; p \leq 0.05\right)$. Based on these findings, it was concluded that project assessment and mechanical talent had an influence on the technical drawing learning achievement of $X$ TKRO class at SMK Negeri 3 Singaraja.
\end{abstract}

Keywords: authentic assessment, technical drawing learning achievement, mechanical talent 


\section{PENDAHULUAN}

Perkembangan ilmu pengetahuan dan teknologi dewasa ini melaju dengan sangat pesat. Hadirnya era Masyarakat Ekonomi Asean (MEA) yang diiringi dengan era Revolusi Industri 4.0 memberikan tantangan yang cukup berat dan kompleks bagi lembaga pendidikan di Indonesia. Untuk menghadapi perkembangan dan kemajuan teknologi tersebut lembaga pendidikan harus dapat menyesuaikan diri dengan perkembangan yang terjadi, terutama dalam menyiapkan sumber daya manusia yang berkualitas. Lembaga pendidikan di Indonesia harus mampu menghasilkan lulusan yang memiliki nilai tambah sesuai kebutuhan pasar kerja, yaitu lulusan yang berkarakter, kompeten dan inovatif.

Dalam Undang-undang Nomor 20 Tahun 2003 disebutkan bahwa pendidikan merupakan usaha sadar dan terencana untuk mewujudkan suasana belajar dan proses pembelajaran agar peserta didik secara aktif mengembangkan potensi dirinya untuk memiliki kekuatan spiritual keagamaan, pengendalian diri, kepribadian, kecerdasan, akhlak mulia, serta keterampilan yang diperlukan dirinya, masyarakat, bangsa dan negara. Jadi pendidikan merupakan usaha sadar agar manusia dapat mengembangkan potensi dirinya melalui proses pembelajaran.

Sekolah sebagai salah satu lembaga yang bergerak di bidang pendidikan merupakan salah satu sarana untuk menciptakan dan meningkatkan kualitas sumber daya manusia. Sekolah juga memiliki peran penting dalam mempersiapkan peserta didik untuk mampu beradaptasi dengan lingkungannya, baik di dunia kerja maupun di masyarakat. Dalam rangka menyiapkan sumber daya manusia yang relevan dengan kebutuhan, sektor pendidikan menunjuk Sekolah Menengah Kejuruan (SMK) sebagai wahana penyelenggara program pendidikan dan pelatihan di bidang kejuruan bagi peserta didiknya.

Jurusan Teknik Kendaraan Ringan Otomotif (TKRO) merupakan salah satu jurusan di SMK Negeri 3 Singaraja yang bertujuan mempersiapkan lulusan yang kompeten dalam bidang mekanik, service, dan maintenance terhadap berbagai jenis kendaraan ringan khususnya otomotif. Oleh karena itu, pada proses pembelajaran di sekolah kompetensi yang dikembangkan mengacu pada Keputusan Menteri Tenaga Kerja dan Transmigrasi Nomor 116 Tahun 2004 tentang Standar Kompetensi Kerja Nasional Indonesia (SKKNI) Sektor Otomotif pada Sub Sektor Kendaraan Ringan adalah engine, power train, chasis \& suspension, electrical, dan body painting.

Salah satu faktor yang mempengaruhi keberhasilan peserta didik mencapai kompetensi yang diharapkan adalah faktor pendidik. Pendidik harus mampu memberikan ruang lingkup kepada peserta didik untuk mengeksplorasi materi pelajaran baik dengan memberikan tugas, baik berupa suatu proyek ataupun mengharuskan peserta didik untuk melakukan unjuk kerja. Peserta didik dengan sendirinya akan melakukan, menganalisis, menghubungkan, menentukan dan memberi intepretasi dari apa yang dilakukannya. Pendidik juga harus dapat menetapkan apa yang dapat diperoleh atau dicapai dari proses pembelajaran yang telah diselenggarakan. Selanjutnya pendidik harus dapat menetapkan apakah program yang direncanakan dapat terlaksana sesuai dengan yang diharapakan, dalam arti bahwa kompetensi yang harus dimiliki peserta didik sesuai dengan harapan. Semua ini dapat diketahui dan terjawab, jika pendidik sudah melakukan asesmen dengan baik.

Stark dan Thomas (1994:46) mendefinisikan asesmen sebagai proses yang menyediakan informasi tentang individu peserta didik, tentang kurikulum atau program, tentang institusi atau segala sesuatu yang berkaitan dengan sistem institusi. Selanjutnya Popham (1995:3) memberi definisi asesmen dalam pembelajaran adalah suatu proses atau upaya formal pengumpulan informasi yang berkaitan dengan variabel-variabel penting pembelajaran sebagai bahan dalam pengambilan keputusan oleh pendidik untuk memperbaiki proses dan hasil belajar peserta didik. 
Faktor penting lainnya yang mempengaruhi pencapaian kompetensi yang diharapkan selain faktor pendidik adalah faktor peserta didik itu sendiri, yaitu berhubungan dengan bakat yang dimilikinya. Sunarto (2008:121) menyatakan bahwa bakat memungkinkan seseorang untuk mencapai prestasi dalam bidang tertentu, akan tetapi perlu latihan, pengetahuan, pengalaman dan motivasi agar bakat itu dapat terwujud. Dalam aspek keterampilan, peserta didik yang memiliki bakat rendah dalam bidang mekanik akan mendapatkan kesulitan dalam memahami dan mempelajari mata pelajaran yang bersifat kejuruan atau mata pelajaran produktif khususnya di SMK.

Bakat peserta didik sering tidak dapat terealisasikan dengan baik dikarenakan fasilitas belajar baik teori maupun praktik di sekolah masih kurang, sehingga potensi bakat peserta didik tidak dapat berkembang dengan maksimal. Selain itu, faktor lain yang menghambat berkembangnya potensi bakat peserta didik adalah kemampuan ekonomi orang tua terbatas sehingga tidak mampu menyekolahkan anaknya ke sekolah yang fasilitas belajarnya lebih lengkap dan pastinya biaya sekolahnya lebih mahal. Dengan demikian peserta didik tersebut belajar dengan fasilitas yang kurang memadai sehingga bakat atau potensi yang ada pada peserta didik tersebut tidak bisa berkembang dengan baik.

Mata pelajaran gambar teknik merupakan mata pelajaran praktikum yang sangat penting pada Jurusan TKRO di SMK Negeri 3 Singaraja. Salah satu faktor untuk menunjang hasil belajar gambar teknik ini yaitu tingkat pemahaman teori dasar menggambar teknik dan melakukan praktek dalam menggambar. Dalam melakukan praktikum gambar teknik, peserta didik tidak hanya dituntut untuk dapat memahami parameter-parameter ukuran gambar saja, namun juga dituntut untuk terampil dalam menggambar suatu benda teknik. Banyak sekali parameterparameter mata pelajaran gambar teknik yang harus diketahui dan dipahami peserta didik, misalnya saja dalam melakukan memilih peralatan dan kelengkapan gambar teknik, memahami garis-garis gambar teknik sesuai bentuk dan fungsi garis, memahami huruf, angka dan etiket gambar teknik, dan lain sebagainya. Parameter tersebut didapatkan dalam teori mata pelajaran gambar teknik. Dari observasi yang dilakukan peneliti di Kelas X TKRO SMK Negeri 3 Singaraja, diketahui tingkat pemahaman teori mata pelajaran gambar teknik peserta didik masih dalam kategori rendah. Hal tersebut dapat dilihat pada saat peserta didik melaksanakan praktikum mata pelajaran gambar teknik tanpa mengaplikasikan parameter gambar teknik yang telah diajarkan pada teori mata pelajaran gambar teknik, peserta didik lebih cenderung ikut-ikutan dengan temannya ketika praktikum. Selain itu juga fasilitas yang tersedia di sekolah berpengaruh terhadap hasil belajar peserta didik. Fasilitas yang memadai akan membuat proses pembelajaran akan berlangsung dengan baik, sehingga standar kompetensi dapat dicapai oleh peserta didik.

Observasi awal yang dilakukan oleh peneliti di Kelas X TKRO SMK Negeri 3 Singaraja memperlihatkan bahwa kegiatan pembelajaran mata pelajaran gambar teknik yang dikembangkan di kelas menggunakan metode praktikum dan tanya jawab, pendidik sudah mampu mengajak peserta didik untuk perlahanlahan aktif dalam mengungkapkan gagasan dan menjawab pertanyaan pendidik. Namun dalam mengungkapkan pertanyaan dan gagasan dari pendidik, gagasan dan jawaban yang diungkapkan peserta didik masih pada taraf aspek kognitif pengetahuan dan pemahaman. Peneliti juga melakukan wawancara dengan pendidik pada mata pelajaran yang bersangkutan untuk menanyakan mengenai asesmen yang diterapkan oleh pendidik. Dari hasil wawancara dan pengamatan pada tugas-tugas individu peserta didik, terlihat tugas yang dikerjakan masih berupa data dan fakta yang belum dilengkapi dengan analisis peserta didik terhadap pertanyaanpertanyaan dalam tugas yang diberikan, sedangkan keterkaitan antara fakta-fakta dan pemecahan masalah belum mereka kuasai. 
Asesmen dalam pembelajaran gambar teknik yang diterapkan oleh pendidik berupa asesmen konvensional dengan memberikan tugas individu berdasarkan prosedur pembuatan gambar dan menilai keaktifan peserta didik tersebut belum mampu membuat peserta didik memiliki kemampuan menganalisis. Hal ini juga diungkapkan oleh pendidik bersangkutan bahwa kemampuan menganalisis peserta didik sebagian besar masih sangat rendah. Mata pelajaran gambar teknik masih dianggap hafalan dari garis-garis, huruf, angka, sketsa dan sebagainya sehingga kemampuan kognitif yang ada dalam diri peserta didik sebagian besar adalah kemampuan mengingat dan memahami.

Selain itu, asesmen yang digunakan di kelas belum mampu mengukur aspek kognitif dan keterampilan berpikir peserta didik dalam mengerjakan tugas atau tes mata pelajaran gambar teknik. Seperti dikatakan oleh Nitko (2001:5) bahwa kegiatan asesmen harus dirancang oleh pendidik dengan sebaik mungkin sehingga mampu mengukur apa yang seharusnya diukur, baik aspek kognitif, afektif, maupun psikomotorik peserta didik. Walaupun dalam kegiatan pembelajaran kelas didukung dengan strategi atau metode pembelajaran yang baik, tanpa didukung oleh penggunaan asesmen yang baik pula, hal ini akan menyebabkan proses pembelajaran yang dilakukan tidak sebanding dengan hasil pencapaian kompetensi peserta didik selama mempelajari materi pelajaran yang bersangkutan.

Asesmen proyek dan asesmen kinerja merupakan bagian dari asesmen otentik, bertujuan untuk menilai kemampuan peserta didik terkait dengan dunia nyata, yakni bagaimana peserta didik mengaplikasikan pengetahuan dan keterampilannya ke dalam tugas-tugas nyata yang diberikan dan disesuaikan dengan kebutuhan peserta didik. Dengan asesmen otentik, akan diperoleh informasi yang akurat untuk melihat kemampuan peserta didik. Asesmen otentik merupakan suatu asesmen penampilan peserta didik dalam berbagai aktivitas tertentu berdasarkan kemampuan yang dimilikinya.
Newman dan Wehlage (1993:12) menyatakan bahwa asesmen otentik adalah proses pengumpulan data di mana peserta didik memahami dan menghasilkan pengetahuan yang bermakna. Menurut Wiggins (dalam Custer dkk., 2000:3), asesmen otentik memuat tugas-tugas dan prosedurprosedur di mana peserta didik diminta menerapkan pengetahuan dan keterampilan untuk menyelesaikan masalah-masalah dunia nyata dan memberikan tugas-tugas yang otentik. Custer dkk. (2000:4) menyatakan bahwa asesmen otentik menuntut aplikasi realworld dari pengetahuan dan keterampilan yang bermakna. Jadi asesmen otentik, menuntut peserta didik melakukan tugastugas real-world yang bermakna dari pengetahuan dan keterampilanketerampilan yang esensial.

O'Neill dkk. (2007:14) menyatakan bahwa asesmen otentik memberikan data yang lebih lengkap tentang kemampuan peserta didik yang didasarkan atas kegiatan pembelajaran. Dengan asesmen otentik peserta didik akan terdorong untuk mengembangkan pemikiran yang lebih kritis dalam menghadapi berbagai permasalahan dalam belajar, karena asesmen otentik menuntut peserta didik melibatkan keterampilan berpikir tingkat tinggi dan kemampuan mengkoordinasi pengetahuan yang lebih luas dalam menyelesaikan pekerjaan, tugas-tugas atau permasalahan yang dihadapi.

Pada asesmen proyek, kegiatan penilaian dilakukan pendidik dengan mengamati dan membuat pertimbangan terhadap suatu tugas peserta didik yang mencakup beberapa kompetensi yang harus diselesaikan oleh peserta didik dalam waktu periode tertentu. Tugas tersebut dapat berupa investigasi terhadap suatu proses atau kejadian yang dimulai dari perencanaan, pengumpulan data, pengorganisasian, pengolahan data dan penyajian data. Sementara itu, pada asesmen kinerja kegiatan penilaian dilakukan pendidik dengan mengamati dan membuat pertimbangan tentang demonstrasi peserta didik dalam hal kecakapan dan menghasilkan suatu produk. Menurut Johnson \& Johnson 
(dalam Ratumanan 2006:110) penilaian kinerja adalah koleksi informasi yang berkaitan dengan demonstrasi prestasi yang meliputi penampilan tugas atau himpunan tugas secara aktual, seperti eksperimen, percakapan, menulis cerita, atau mengoperasikan mesin.

Kedua asesmen otentik di atas dapat menuntut peserta didik untuk mengerjakan atau menyelesaikan suatu tugas yang menghasilkan produk, kinerja, atau uraian dari suatu pertanyaan yang menunjukkan kemampuan dan keterampilan berpikirnya. Tugas-tugas yang terkait dengan asesmen otentik ini dapat menumbuhkan rasa ingin tahu dan kemampuan peserta didik dalam mencari, menemukan, mengolah dan menggunakan informasi. Secara tidak langsung rasa ingin tahu yang tumbuh dalam diri peserta didik juga akan melatih kemampuannya dalam melakukan analisis dan mencari penyelesaian terhadap permasalah-permasalahan yang ditemuinya dalam mencari jawaban atas keingintahuannya terhadap suatu hal.

Berdasarkan permasalahan tersebut, peneliti perlu melakukan implementasi atau penerapan asesmen otentik yaitu berupa asesmen proyek dan asesmen kinerja dalam memperbaiki kegiatan pembelajaran yang didahului dengan mengukur bakat mekanik yang dimiliki oleh peserta didik, sehingga dapat memberikan gambaran secara menyeluruh mengenai proses pembelajaran sesuai dengan yang diharapkan yang dapat dilihat melalui hasil belajar yang diperoleh oleh peserta didik. Adanya penerapan asesmen otentik melalui pengukuran awal bakat mekanik yang dimiliki oleh peserta didik ini diharapkan menjadi solusi untuk meningkatkan hasil belajar peserta didik dalam mata pelajaran gambar teknik pada Kelas X TKRO di SMK Negeri 3 Singaraja.

\section{METODE}

Pendekatan yang digunakan dalam penelitian ini adalah pendekatan kuantitatif. Menurut Sugiyono (2007:8), pendekatan kuantitatif dapat diartikan sebagai metode penelitian yang berlandaskan pada filsafat penelitian positivisme, digunakan untuk meneliti populasi atau sampel tertentu, teknik pengambilan sampel dilakukan secara random, pengumpulan data menggunakan instrumen tes, analisis data bersifat kuantitatif atau statistik dengan tujuan untuk menguji hipotesis yang telah ditetapkan. Selanjutnya jenis penelitian ini adalah penelitian eksperimen semu (quasi experiment). Suryabrata (2004:92) menyatakan bahwa eksperimen semu adalah rancangan untuk mengungkapkan hubungan sebab-akibat yang melibatkan suatu variabel penelitian. Tujuan eksperimen semu adalah untuk memperoleh informasi yang merupakan perkiraan bagi informasi yang dapat diperoleh dengan eksperimen yang sebenarnya dalam keadaan yang tidak memungkinkan untuk mengontrol atau memanipulasi variabel yang relevan.

Dalam penelitian eksperimen semu ini menggunakan metode single factor independent groups design with us covariate. Rancangan ini menggunakan kelompok yang sudah ada di mana hal ini dikarenakan tidak memungkinkannya dilakukan pengacakan sampel dan tes yang dilakukan hanya berupa post test saja.

Populasi pada penelitian ini adalah peserta didik Kelas X TKRO SMK Negeri 3 Singaraja. Penentuan sampel dilakukan tanpa adanya pengacakan individu, cara ini dipilih dengan mempertimbangkan sulitnya untuk merubah kelas yang sudah terbentuk. Pemilihan cara ini juga berimplikasi pada subjek penelitian sehingga kemungkinan pengaruhpengaruh dari keadaan subjek mengetahui dirinya dilibatkan dalam suatu kegiatan eksperimen dapat dikurangi sehingga penelitian ini benar-benar mampu menggambarkan pengaruh dari perlakuan yang diberikan.

Berdasarkan dari karakteristik populasi yang tidak memungkinkan dilakukan pengacakan individu, pengambilan sampel pada penelitian ini dengan teknik random sampling. Menurut Dantes (2012: 41) teknik random sampling merupakan penarikan sampel secara sederhana dengan cara random. Untuk mengetahui kelompok yang menjadi sampel tidak berbeda secara signifikan, 
maka digunakan hasil ulangan akhir semester sebelumnya untuk mengetahui hasil belajar siswa sebelum dilakukannya eksperimen di mana hasilnya kemudian di analisis dengan Anava satu jalur. Dari hasil analisis diperoleh sampel sejumlah 70 orang yang terdiri dari dua kelas yaitu Kelas X TKRO-1 dan Kelas X TKRO-2.

Selanjutnya untuk memilih kelompok kelas mana yang diberi perlakuan asesmen proyek dan kelompok kelas mana yang diberi perlakuan asesmen kinerja dilakukan pengundian terhadap kedua kelompok kelas tersebut. Dari pengundian yang dilakukan diperoleh hasil yaitu Kelas X TKRO-1 sebagai kelompok sampel dengan penerapan asesmen proyek dan Kelas $X$ TKRO-2 sebagai kelompok sampel dengan penerapan asesmen kinerja. Pada saat pelaksanaan eksperimen kedua kelompok tersebut diberikan materi dan model pelajaran yang sama, yaitu materi mata pelajaran gambar teknik dengan model pembelajaran saintifik.

Variabel dalam penelitian ini terdiri dari variabel bebas, variabel kendali dan variabel terikat. Variabel bebas (faktor) adalah variabel yang ingin diketahui pengaruhnya, yaitu penerapan asesmen proyek $\left(A_{1}\right)$ dan penerapan asesmen kinerja $\left(A_{2}\right)$. Variabel kendali (kovariabel) adalah variabel yang dikendalikan oleh peneliti dan memiliki pengaruh terhadap variabel terikat, yaitu bakat mekanik (X). Variabel terikat adalah variabel yang dipengaruhi atau menjadi akibat karena adanya variabel bebas dan variabel kendali, yaitu hasil belajar gambar teknik siswa $(Y)$.

Data penelitian dikumpulkan dengan menggunakan dua instrumen, yaitu: instrumen tes bakat mekanik berupa tes pilihan ganda (obyektif) dan instrumen tes hasil belajar gambar teknik berupa tes uraian. Sebelum digunakan dalam penelitian, terlebih dahulu kedua instrumen tersebut dikonsultasikan dengan pakar (judges) untuk mengetahui validitas isi instrumen tersebut yang dihitung dengan menggunakan rumus Gregory. Setelah itu dilakukan ujicoba lapangan terhadap kedua instrumen untuk mengetahui nilai konsistensi internal (menggunakan rumus koefisien korelasi butir-total), reliabilitas (menggunakan rumus KR-20 untuk instrumen tes obyektif dan rumus Alpha Cronbach untuk instrumen tes uraian), daya pembeda, dan tingkat kesukarannya. Ujicoba lapangan dari kedua instrumen dilakukan di Kelas $X$ TKRO-3 SMK Negeri 3 Singaraja.

Dari hasil uji coba lapangan yang dilakukan dengan jumlah 40 butir soal instrumen tes bakat mekanik, diketahui dalam pengujian konsistensi internal 35 butir soal memiliki nilai konsistensi internal yang tinggi sedangkan 5 butir soal memiliki nilai konsistensi internal yang rendah atau digugurkan, reliabilitas instrumen sebesar 0,929 (sangat tinggi), daya pembeda seluruh butir soal yang terkategori baik dan tingkat kesukaran seluruh butir soal yang terkatekori sedang. Sedangkan dengan jumlah 12 butir soal instrumen tes hasil belajar gambar teknik, diketahui dalam pengujian konsistensi internal 10 butir soal memiliki nilai konsistensi internal yang tinggi sedangkan 2 butir soal memiliki nilai konsistensi internal yang rendah atau digugurkan, reliabilitas instrumen sebesar 0,858 (sangat tinggi), daya pembeda seluruh butir soal yang terkategori baik dan tingkat kesukaran seluruh butir soal yang terkatekori sedang.

Pelaksanaan pertemuan pada penelitian ini dilakukan sebanyak 8 kali di masing-masing kelas eksperimen. Pembelajaran di kelas pada mata pelajaran gambar teknik dilakukan sesuai dengan langkah-langkah dari masingmasing model asesmen yang diterapkan. Data bakat mekanik diambil di awal kegiatan eksperimen, sedangkan data hasil belajar gambar teknik diambil di akhir kegiatan eksperimen.

Pengujian prasyarat analisis data dilakukan terlebih dahulu sebelum dilakukan pengujian hipotesis. Pengujianpengujian yang dilakukan dalam pengujian prasyarat analisis data adalah pengujian normalitas sebaran data (menggunakan analisis Kolmogorov-Smirnov), pengujian homogenitas varians data (menggunakan analisis Levene) dan pengujian linearitas keberartian arah regresi (menggunakan analisis regresi (Anareg) sederhana). 
Setelah pengujian prasyarat analisis data terpenuhi kemudian dilakukan pengujian hipotesis. Hipotesis pertama dianalisis dengan menggunakan uji-t, hipotesis kedua dianalisis dengan menggunakan analisis kovarian (Anakova) satu jalur dan hipotesis ketiga dianalisis menggunakan Anareg sederhana satu prediktor untuk mengetahui signifikansi koefisien korelasinya.

\section{HASIL DAN PEMBAHASAN}

Data yang diperoleh pada penelitian ini adalah data tentang bakat mekanik dan data tentang hasil belajar gambar teknik. Ringkasan hasil perhitungan dari tiap kelompok data berdasarkan skor yang diperoleh dari hasil pengumpulan data yang dilakukan dapat diikhtisarkan pada tabel berikut.

Tabel 1. Ringkasan Skor Bakat Mekanik dan Hasil Belajar Gambar Teknik Siswa.

\begin{tabular}{ccccc}
\hline \multirow{2}{*}{ Statistik } & \multicolumn{2}{c}{ Penerapan Asesmen Proyek } & \multicolumn{2}{c}{ Penerapan Asesmen Kinerja } \\
\cline { 2 - 5 } & Bakat Mekanik & Hasil Belajar & Bakat Mekanik & Hasil Belajar \\
\hline Rata-rata & 19,882 & 22,176 & 19,528 & 20,306 \\
Modus & 16 & 19,1 & 18 & 16,72 \\
Median & 19,5 & 19,85 & 17 & 20,26 \\
Standar Deviasi & 6,375 & 3,545 & 5,769 & 3,249 \\
Varians & 40,652 & 12,567 & 33,284 & 10,556 \\
Skor Min. & 12 & 18 & 11 & 16 \\
Skor Max. & 32 & 29 & 31 & 28 \\
Rentang & 20 & 11 & 20 & 12 \\
\hline
\end{tabular}

Untuk skor bakat mekanik, diketahui bahwa kelompok siswa dengan penerapan asesmen proyek memiliki rata-rata skor sebesar 19,882 yang terletak pada interval $14 \leq x<21$, pada kategori sedang. Secara lebih rinci dapat dinyatakan bahwa sebanyak $17,6 \%$ siswa memperoleh skor disekitar rata-rata, sebanyak $47 \%$ siswa mendapat skor dibawah rata-rata dan sebanyak 35,4\% siswa mendapat skor diatas rata-rata. Sedangkan kelompok siswa dengan penerapan asesmen kinerja memiliki rata-rata skor sebesar 19,528 yang terletak pada interval $14 \leq x<21$, pada kategori sedang. Secara lebih rinci dapat dinyatakan bahwa sebanyak $16,7 \%$ siswa memperoleh skor disekitar rata-rata, sebanyak 58,4\% siswa mendapat skor dibawah rata-rata dan sebanyak 24,9\% siswa mendapat skor diatas rata-rata.

Selanjutnya untuk skor hasil belajar gambar teknik, diketahui bahwa kelompok siswa dengan penerapan asesmen proyek memiliki rata-rata skor sebesar 22,176 yang terletak pada interval $17,5 \leq x<24$, pada kategori tinggi. Secara lebih rinci dapat dinyatakan bahwa sebanyak $14,7 \%$ siswa memperoleh skor disekitar rata-rata, sebanyak 53\% siswa mendapat skor dibawah rata-rata dan sebanyak $32,3 \%$ siswa mendapat skor diatas rata-rata. Sedangkan kelompok siswa dengan penerapan asesmen kinerja memiliki ratarata skor sebesar 20,306 yang terletak pada interval $17,5 \leq x<24$, pada kategori tinggi. Secara lebih rinci dapat dinyatakan bahwa sebanyak $22,2 \%$ siswa memperoleh skor disekitar rata-rata, sebanyak $36,1 \%$ siswa mendapat skor dibawah rata-rata dan sebanyak 24,9\% siswa mendapat skor diatas rata-rata.

Pertama, hasil pengujian hipotesis pertama menggunakan uji-t telah berhasil menolak $\mathrm{H}_{0}$ dan menerima $\mathrm{H}_{1}$ ( $\mathrm{t}_{\text {hit }}=2,303$; $p \leq 0,05)$ dengan nilai rata-rata pada kelompok kelas penerapan asesmen proyek sebesar 22,18 dan nilai rata-rata pada kelompok kelas penerapan asesmen kinerja sebesar 20,31 yang berarti bahwa terdapat perbedaan pengaruh yang signifikan dari implementasi asesmen proyek dan asesmen kinerja dalam pembelajaran terhadap hasil belajar gambar teknik pada Kelas X TKRO di SMK Negeri 3 Singaraja, dimana hasil belajar gambar teknik siswa dengan penerapan asesmen proyek lebih tinggi daripada siswa dengan penerapan asesmen kinerja. Ringkasan hasil uji-t dapat dilihat pada tabel berikut. 
Jurnal_ep, Vol. 9 No. 2, Agustus 2019

Tabel 2. Ringkasan Pengujian-t.

\begin{tabular}{|c|c|c|c|c|c|}
\hline Kelompok & $\begin{array}{l}\text { Jumlah } \\
\text { Sampel }\end{array}$ & Rata-rata & $t_{\text {hit }}$ & $t_{\operatorname{tab}(0,05)}$ & $\begin{array}{c}\mathrm{p} \\
\text { (Sig. (2-tailed)) }\end{array}$ \\
\hline $\begin{array}{l}\text { Kelas X TKRO-1 } \\
\text { Asesmen Proyek }\end{array}$ & 34 & 22,18 & \multirow[t]{2}{*}{2,303} & \multirow[t]{2}{*}{1,667} & \multirow[t]{2}{*}{0,024} \\
\hline $\begin{array}{l}\text { Kelas X TKRO-2 } \\
\text { Asesmen Kinerja }\end{array}$ & 36 & 20,31 & & & \\
\hline
\end{tabular}

Skor rata-rata hasil belajar gambar teknik siswa yang mendapat penerapan asesmen proyek adalah 22,18 yang termasuk dalam kategori tinggi (100\%) dan skor rata-rata hasil belajar siswa dengan penerapan asesmen kinerja adalah 20,31 yang termasuk dalam kategori tinggi juga $(69,4 \%)$ dari skor maksimum yang bisa dicapai yaitu 30 . Sehingga secara keseluruhan, hasil belajar gambar teknik siswa dengan penerapan asesmen proyek lebih baik daripada hasil belajar siswa dengan penerapan asesmen kinerja.

Melalui penerapan asesmen proyek dalam pembelajaran, siswa dituntut untuk selalu menyelesaikan tugas-tugas yang diberikan dengan tepat waktu, sesuai dengan kriteria yang ditetapkan, bertanggungjawab, mengasah kemampuan berpikir dalam tingkatan yang lebih tinggi melalui identifikasi masalah, analisis masalah dan mencari solusi terkait permasalahan yang ditemukan dalam suatau penyelesaian tugastugasnya. Siswa juga dilatih untuk melakukan evaluasi terhadap tugas-tugas yang dikerjakannya, kendala-kendala yang ditemui, dan kesalahan-kesalahan yang dilakukan sehingga dengan demikian akan mampu meningkatkan kualitas terhadap tugas yang diberikan selanjutnya di mana ini tentu berdampak pada peningkatan hasil belajarnya.

Kegiatan pembelajaran akan bermakna apabila siswa mendapatkan hasil yang nyata berdasarkan konsepkonsep yang diperoleh dan di alami sendiri oleh siswa tersebut, sehingga ini diharapkan mampu memberi dampak yang positif terhadap kemampuan siswa dalam menerapkan hasil belajarnya sencara utuh dan menyeluruh nantinya di dunia kerja maupun dalam kehidupan bermasyarakat.
Asesmen proyek sebagai asesmen yang mengedepankan project work atau pembelajaran yang terstandar, bermuatan pedagogis dan bermakna bagi siswa juga memberikan kesempatan bagi siswa untuk mengekspresikan kompetensi yang dikuasainya secara utuh. Selain itu asesmen proyek juga menghasilkan nilai penguasaan kompetensi yang dapat dipertanggungjawabkan dan memiliki kelayakan untuk di sertifikasi. Asesmen proyek dikembangkan dengan melibatkan siswa secara aktif dalam proses pembelajaran yaitu mulai dari perencanaan, pelaksanaan hingga penilaian yang dilakukan. Asesmen proyek dilaksanakan dengan melihat kemampuan yang dimiliki oleh siswa, sehingga dengan demikian siswa akan termotivasi untuk belajar terus menerus dan menekankan keterkaitan materi serta tugas-tugas yang diberikan dengan kehidupan nyata.

Sementara itu asesmen kinerja cenderung membatasi kesempatan siswa untuk mengekpesikan kompetensi yang dikuasainya sehingga potensi-potensi siswa secara utuh tidak terlihat. Asesmen kinerja sendiri cenderung terpusat pada guru dalam menentukan tahapan-tahapan dalam proses pembelajaran yang dilakukan, sehingga siswa tidak berani melakukan hal-hal yang memacu kreativitas dan kemampuan berpikirnya hanya terbatas pada penyelesaian suatu pekerjaan atau tugas berdasarkan ketentuan-ketentuan yang telah ditentukan pada tahapan pekerjaannya. Pada rancangan pembelajarannya guru tidak memperhatikan kemampuan awal yang dimiliki oleh siswanya. Proses pembelajaran pun berlangsung satu arah, di mana peran guru yang seharusnya sebagai fasilitator, motivator dan mediator tergantikan oleh peran yang lebih otoriter dalam menentukan materi pembelajaran, 
pemberian contoh dan tugas-tugas yang dikerjakan siswa. Tujuan dalam pembelajaran akan dicapai apabila guru mampu mendemonstrasikan pengetahuan dan keterampilannya sebagai pendidik dengan tepat kepada siswa, sehingga materi yang dikembangkan dalam pembelajaran cenderung disesuaikan berdasarkan kemampuan dan selera guru yang mengajar. Kegiatan pembelajaran seperti ini tidak dapat menciptakan situasi belajar mengajar yang aktif, melainkan memiliki kecenderungan menjadikan siswa pasif menerima perintah-perintah yang dikerjakan. Hal ini mengakibatkan pengetahuan yang dimiliki oleh siswa hanya sebatas transfer pengetahuan yang dimiliki oleh guru, yang mengakibatkan hasil belajar siswa menjadi kurang baik.

Maka, tampak jelas bahwa asesmen proyek lebih baik diterapkan daripada asesmen kinerja dalam pembelajaran gambar teknik, karena dengan penerapan asesmen proyek siswa akan terlibat secara aktif dan nyata dalam dalam kegiatan pembelajaran sehingga kemampuan-kemapuan yang di miliki oleh siswa dapat di lihat secara utuh oleh guru. Oleh karena itu hasil belajar gambar teknik siswa yang diberikan penerapan asesmen proyek lebih baik daripada hasil belajar gambar teknik siswa yang diberikan penerapan asesmen kinerja.

Kedua, hasil pengujian hipotesis kedua menggunakan Anakova satu jalur telah berhasil menolak $\mathrm{H}_{0}$ dan menerima $\mathrm{H}_{1}\left(\mathrm{~F}_{\text {hit }}{ }^{*}=49,204 ; \mathrm{p} \leq 0,05\right)$, di mana nilai rata-rata bakat mekanik kedua kelompok sebesar 19,70 , nilai rata-rata hasil belajar gambar teknik pada kelompok kelas penerapan asesmen proyek sebesar 22,079 dan pada kelompok kelas penerapan asesmen kinerja sebesar 20,398. Ini berarti setelah diadakan pengendalian bakat mekanik peserta didik, terdapat perbedaan pengaruh yang signifikan dari implementasi asesmen proyek dan asesmen kinerja dalam pembelajaran terhadap hasil belajar gambar teknik pada Kelas X TKRO di SMK Negeri 3 Singaraja, di mana hasil belajar gambar teknik siswa yang diberikan penerapan asesmen proyek lebih tinggi daripada hasil belajar gambar teknik siswa yang diberikan penerapan asesmen kinerja. Ringkasan hasil perhitungan Anakova satu jalur dapat dilihat pada tabel sebagai berikut.

Tabel 3. Ringkasan Anakova Satu Jalur.

\begin{tabular}{|c|c|c|c|c|c|c|}
\hline $\begin{array}{l}\text { Sumber } \\
\text { Variansi }\end{array}$ & $\begin{array}{l}\text { Jumlah } \\
\text { Kudarat }\end{array}$ & $\begin{array}{l}\text { Derajat } \\
\text { Bebas }\end{array}$ & $\begin{array}{c}\text { Rerata Jumlah } \\
\text { Kuadrat }\end{array}$ & $F^{\star}$ hit & $\mathrm{F}_{\mathrm{tab}}$ & Sig. \\
\hline Antar & 49,381 & 1 & 49,381 & \multirow{3}{*}{49,204} & \multirow{3}{*}{3,98} & \multirow{3}{*}{0,000} \\
\hline Dalam & 67,240 & 67 & 1,004 & & & \\
\hline Total & 116,621 & 68 & - & & & \\
\hline
\end{tabular}

Pengujian hipotesis kedua ini menunjukkan bahwa rata-rata skor hasil belajar gambar teknik siswa dengan penerapan asesmen proyek tetap lebih baik daripada hasil belajar gambar teknik siswa dengan penerapan asesmen kinerja walaupun bakat mekanik yang dimiliki oleh siswa telah dikendalikan. Penggunaan Anakova satu jalur ini memiliki tujuan untuk melakukan pengendalian statistik dan pembersihan atau reduksi terhadap pengaruh-pengaruh dari variabel luar seperti bakat mekanik terdapat hasil belajar gambar teknik. Sehingga dapat di lihat pengaruh yang lebih bersih dan murni dari penerapan asesmen proyek dan asesmen kinerja dalam pembelajaran terhadap hasil belajar gambar teknik yang dilakukan.

Dari hasil analisis, bakat mekanik kedua kelompok memiliki rata-rata skor bakat mekanik dalam kategori sedang, hal ini berarti bahwa kovariabel bakat mekanik dalam penelitian ini memiliki potensi untuk mempengaruhi hasil belajar gambar teknik siswa. Pengaruh positif dari kovariabel disebabkan oleh adanya kemampuan potensial dari siswa untuk menerima dan memahami prinsip perhitungan bengkel, pengetahuan alat, pengetahuan mekanik, dan pendalaman pengetahuan mekanik serta hubungan dengan materi 
pembelajaran gambar teknik yang dipelajari siswa. Struktur materi pembelajaran gambar teknik ini sesuai dengan prinsip-prinsip yang berhubungan dengan bakat mekanik siswa, di mana ini tercermin dalam bentuk perilaku yang bisa diamati dari adanya kemampuan siswa dalam memahami dan menyelesaikan tes bakat mekanik sebagai pengetahuan berdasarkan pemahaman prinsip prosedural dari perhitungan bengkel dan pendalaman pengetahuan mekanik serta prinsip alamiah yang tampak setelah kegiatan pembelajaran berakhir.

Bakat mekanik memiliki pengaruh yang berbeda dalam pembelajaran gambar teknik antara penerapan asesmen proyek dan asesmen kinerja, ini dilihat berdasarkan rata-rata skor hasil belajar gambar teknik pada kelompok asesmen proyek sebesar 22,079 sedangkan kelompok asemen kinerja sebesar 20,398. Hal ini berarti memang benar skor ratarata hasil belajar gambar teknik kelompok asesmen proyek dan kelompok asesmen kinerja berbeda, dimana rata-rata skor hasil belajar gambar teknik pada kelompok asesmen proyek lebih besar dibandingkan kelompok asesmen kinerja walaupun bakat mekanik telah dikendalikan.

Ketiga, bakat mekanik adalah salah satu potensi dasar yang dimiliki oleh siswa untuk dapat mengungkapkan prinsipprinsip perhitungan bengkel, pengetahuan alat, pengetahuan mekanik, dan pendalaman pengetahuan mekanik pada saat siswa melihatnya atau mengalaminya dalam kejadian sehari-hari. Dalam kegiatan pembelajaran, bakat mekanik yang dimiliki oleh siswa sebagai potensi dasar akan mampu dimaksimalkan apabila guru mampu memberikan penerapan asesmen yang tepat juga sehingga dapat membantu dan meningkatkan hasil belajar yang dicapai oleh siswa. Selain itu, bakat mekanik yang dimiliki oleh siswa juga memiliki peranan yang sangat besar untuk mencapai tujuan-tujuan pembelajaran yang telah ditetapkan. Hal ini dikarenakan dengan semakin tingginya bakat mekanik yang dimiliki, siswa akan memiliki rasa dan sikap yang lebih siap secara mental untuk mengikuti kegiatan pembelajaran. Kesiapan mental ini tentunya akan memberi pengaruh terhadap kepercayaan diri peserta didik didalam menyelesaikan pekerjaan-pekerjaan, tugas-tugas ataupun tes yang diberikan melalui kegiatan pembelajaran yang dilakukan. Dalam pembelajaran gambar teknik, materi yang disampaikan akan lebih banyak menyangkut fenomena-fenoma dalam kehidupan nyata dan keseharian siswa yang berkaitan dengan perkembanganperkembangan ilmu pengetahuan dan teknologi di masyarakat. Kontribusi bakat mekanik dalam pembelajaran terhadap hasil belajar gambar teknik setelah diberi penerapan asesmen proyek dan penerapan asesmen kinerja dapat dijelaskan berdasarkan hasil pengujian Anareg sederhana.

Dari hasil pengujian yang telah dilakukan, diketahui bahwa nilai koefisien determinasi atau $R$ Square sebesar 0,862. Nilai $R$ Square sebesar 0,862 ini berasal dari pengkuadratan nilai koefisien regresi $(R)$, yaitu sebesar $0,929 \times 0,929=0,862$. Besarnya angka koefisien determinasi tersebut dalam persentase adalah sebesar $86,2 \%$. Angka tersebut mengandung arti bahwa variabel bakat mekanik (X) memberi berpengaruh yang signifikan terhadap variabel hasil belajar gambar teknik (Y) dengan koefisien determinasi sebesar $86,2 \%$, sedangkan sisanya $13,8 \%$ $(100 \%-86,2 \%)$ dipengaruhi oleh variabel lain di luar persamaan regresi ini atau variabel yang tidak diteliti.

Kontribusi yang ditunjukkan oleh bakat mekanik ini menegaskan bahwa bakat mekanik mempunyai peranan penting dalam pembelajaran terhadap hasil belajar gambar teknik baik pada kelompok siswa dengan penerapan asesmen proyek maupun pada kelompok siswa dengan penerapan asesmen kinerja. Bakat mekanik merupakan salah satu faktor penentu keberhasilan peserta didik dalam menyelesaikan pembelajaran gambar teknik dan menjadi bagian yang tidak terpisahkan dari kompetensi yang harusnya mampu secara utuh dikuasai oleh peserta didik di akhir kegiatan pembelajaran gambar teknik. 


\section{PENUTUP}

Simpulan: berdasarkan analisis data yang telah dipaparkan pada hasil penelitian di atas, diperoleh beberapa temuan sebagai berikut.

1) Terdapat perbedaan pengaruh yang signifikan dari implementasi asesmen proyek dan asesmen kinerja dalam pembelajaran terhadap hasil belajar gambar teknik pada Kelas X TKRO di SMK Negeri 3 Singaraja, dimana hasil belajar gambar teknik siswa yang diberikan penerapan asesmen proyek lebih tinggi daripada hasil belajar gambar teknik siswa yang diberikan penerapan asesmen kinerja.

2) Setelah diadakan pengendalian bakat mekanik peserta didik, terdapat perbedaan pengaruh yang signifikan dari implementasi asesmen proyek dan asesmen kinerja dalam pembelajaran terhadap hasil belajar gambar teknik pada Kelas X TKRO di SMK Negeri 3 Singaraja, di mana bakat mekanik dikendalikan pada level 19,70 dan hasil belajar gambar teknik siswa yang diberikan penerapan asesmen proyek lebih tinggi daripada hasil belajar gambar teknik siswa yang diberikan penerapan asesmen kinerja.

3) Terdapat kontribusi yang signifikan dari bakat mekanik dalam pembelajaran terhadap hasil belajar gambar teknik pada Kelas X TKRO di SMK Negeri 3 Singaraja dengan koefisien determinasi sebesar $86,2 \%$, sedangkan sisanya $17,4 \%(100 \%-82,6 \%)$ dipengaruhi oleh variabel lain di luar persamaan regresi ini atau variabel yang tidak diteliti.

Atas dasar temuan di atas, dapat disimpulkan bahwa hasil belajar gambar teknik siswa dengan penerapan asesmen proyek lebih baik daripada hasil belajar gambar teknik siswa dengan penerapan asesmen kinerja. Perbedaan ini konsisten walaupun telah dilakukan pengendalian bakat mekanik siswa dan bakat mekanik ini sendiri turut memberi kontribusi terhadapat hasil belajar gambar teknik siswa di Kelas X TKRO SMK Negeri 3 Singaraja.

Saran: dalam melakukan kegiatan pembelajaran khususnya yang berkaitan dengan praktikum, perlu diperhatikan penerapan asesmen yang akan diberikan kepada peserta didik agar dapat menggali potensi-potensi yang dimiliki oleh peserta didik. Potensi yang dimaksud dalam hal ini adalah bakat mekanik peserta didik, di mana dengan penerapan asesmen yang sesuai potensi bakat mekanik yang ada dan melekat pada peserta didik akan mampu berkembang secara optimal. Bakat mekanik penting diketahui oleh pendidik agar mampu memberikan sentuhan melalui latihan-latihan atau tugas-tugas kepada peserta didik untuk mengembangkan diri sehingga menghasilkan nilai penguasaan kompetensi yang dapat dipertanggungjawabkan serta memberikan kesempatan bagi peserta didik untuk mengekspresikan kompetensi yang dikuasainya secara utuh.

\section{UCAPAN TERIMAKASIH}

Terkait dengan penelitian yang telah dilakukan, penulis mengucapkan terimakasih yang sebesar-besarnya kepada Prof. Dr. I Made Candiasa, MI.Kom. selaku pembimbing I dan Dr. I Nyoman Gita, M.Si. selaku pembimbing II, yang dengan penuh kesabaran, ketelitian, dan keceramatan untuk memberikan bimbingan, motivasi, arahan, saran dan kritik kepada penulis mulai awal penyusunan hingga selesai penelitian ini. Ucapan terimakasih juga penulis ucapkan kepada Drs. I Nyoman Suastika, M.Pd., selaku Kepala SMK Negeri 3 Singaraja yang telah memberikan ijin kepada penulis untuk melakukan penelitian di SMK Negeri 3 Singaraja. Terakhir penulis mengucapkan terimakasih kepada I Wayan Widayana, S.Pd., selaku Guru Mata Pelajaran Gambar Teknik di Kelas X TKRO SMK Negeri 3 Singaraja atas bantuan, saran dan kritik selama penulis melakukan penelitian di Kelas $X$ TKRO SMK Negeri 3 Singaraja.

\section{DAFTAR RUJUKAN}

Custer, R. L. At al. 2000. Using Authentic Assessment in Vocational Education. Clearinghouse on Adults, Career, and Vocational Education. The Ohaio State University. 
Dantes, Nyoman. 2012. Metode Penelitian. Yogyakarta: Andi.

Keputusan Menteri Tenaga Kerja dan Transmigrasi Republik Indonesia Nomor: KEP.116/MEN/VII/2004 Tentang Penetapan Standar Kompetensi Kerja Nasional Indonesia Sektor Otomotif Sub Sektor Kendaraan Ringan.

Newman, F.M. and Wehlage, G.G. 1993. Five Standards of Authentic Instruction. Educational Leadership. April, 8-12.

Nitko, A. 2001. Educational Assessment of Student $3^{\text {rd }}$ Edition. New Jersey: Prentice-Hall, Inc., Upper Saddle River.

O'Neill, G., Huntley-Moore,S. and Race, P. 2007. Case Studies of Good Practices in Assessment of Student Learning in Higher Education. Dublin: AISHE.

Popham, W.J. 1995. Classroom Assessment: What Teacher Need To Know. Los Angeles: Allyn and Bacon.

Ratumanan. 2006. Model Pembelajaran Menciptakan Belajar Mengajar yang Kreatif dan Efektif. Jakarta: Bumi Aksara.

Stark, J.S. and Thomas, A.. 1994. Assessment and Program Evaluation. Needham Heights: Simon \& Schuter Custom Publishing.

Sugiyono. 2007. Metode Penelitian Pendidikan. Bandung: Alfabeta.

Sunarto. 2008. Perkembangan Peserta Didik. Jakarta: PT. Rineke Cipta.

Suryabrata, Sumadi. 2004. Metodologi Penelitian. Jakarta: Raja Grafindo Persada.

Undang-Undang Nomor 20 Tahun 2003 Tentang Tujuan Pendidikan Menengah Kejuruan. 